\title{
Pulmonary Function Tests in Transport Workers Within the Ring Road of Kathmandu Valley
}

\section{Ghimire Dayaram*1, Manna Saurav ${ }^{1}$, Shrestha Esha ${ }^{1}$}

${ }^{1}$ Department of Physiology, National Medical College, Birgunj.

Date of Submission : March 16, 2018

Received in Revised Form : March 26, 2018

Date of Acceptance : April 10, 2018

Date of Publishing : July 30, 2018

\section{ABSTRACT}

Background: Transport workers (drivers and helpers) are exposed to dust and vehicle emissions continuously throughout their duty hours. Most common health hazards on exposure to air pollution is related to respiratory system. The main objective of the study was to measure lung function parameters of transport workers and compare results with those of the general public. This study also aimed to evaluate the effect of job duration on transport workers.

Methods: A cross-sectional comparative study was done in a total of 78 apparently healthy, non-smoking, male transport workers working for at least one year within the Ring Road in Kathmandu valley. The results obtained from these professionals were compared to 78 apparently healthy, non-smoker male general public, working as students in medical college and administrative staff in transport office.

Results: Statistically significant decrease in Forced Vital Capacity (FVC), Forced Expiratory Volume in one second $\left(\mathrm{FEV}_{1}\right)$, Peak Expiratory Flow Rate (PEFR) and Forced Expiratory Flow between ${ }_{25 \%}$ and $75 \%\left(\mathrm{FEF}_{25 \%-75 \%}\right)$ among transport workers was noted as compared to the general public. Transport workers working for more than five years also have deteriorated above mentioned parameters as compared to their colleagues working five years or less in the same profession.
Conclusions: This study concludes that there is an adverse effect of ambient air pollution on pulmonary functions of the transport workers. The findings of this study also demonstrate that the transport workers working in Kathmandu valley for more than five years have deteriorated pulmonary functions.

Keywords: $\mathrm{FEF}_{25 \%-75 \%}, \mathrm{FEV}_{1}, \mathrm{FVC}$, Lung function, PEFR, Transport Workers

*Corresponding Author: Dayaram Ghimire, Department of Physiology, National Medical College, Birgunj, Nepal. Email: dayaramghimire@ gmail.com

\section{INTRODUCTION}

Individuals engaged in various occupations are subjected to health hazards resulting from their exposure to various environmental pollutants. Occupation as transport workers and traffic policemen are directly exposed to ambient air pollutions consisting of automobile exhausts. Air pollution is the disequilibrium condition of the air caused due to the introduction of foreign elements from natural as well as anthropogenic sources to the air so that the air becomes injurious to human. ${ }^{1}$ Pollutants having direct effect on public health include particulate matter (PM), carbon monoxide $(\mathrm{CO})$, ozone $\left(\mathrm{O}_{3}\right)$, nitrogen dioxide $\left(\mathrm{NO}_{2}\right)$ and sulphur dioxide $\left(\mathrm{SO}_{2}\right){ }^{2} \mathrm{In}$ Kathmandu, the major sources of pollution are automobile exhaust, household wastes, brick 
kilns and factories in southern and eastern region of the valley. ${ }^{3}$

The number of automobiles is increasing rapidly these days, so is exhaust. Automobile exhaust generally contains $\mathrm{NO}_{2}$, carbon dioxide $\left(\mathrm{CO}_{2}\right)$, $\mathrm{CO}$, hydrocarbons, benzopyrene, nitroaromatics, benzene, 1,3 betadine, particulates and lead. It is well recognized that the vehicle fumes are a major source of polycyclic aromatic hydrocarbons (PAHs). ${ }^{4}$ Most important traffic-related air pollutants with regard to health effect are particulate matters derived from motor vehicle emissions, abrasion of tires and dispersion of construction materials. ${ }^{5}$ Particulate air pollutant is a mixture of different solid, liquid or solid and different liquid particles suspended in the air. Based on mass and composition, particulate matters in urban environment tend to be divided into two principal groups: coarse particles and fine particles. Particulate matters with size up to $2.5 \mu \mathrm{m}$ are called fine and larger than $2.5 \mu \mathrm{m}$ are coarse. These are denoted by $\mathrm{PM}_{2.5}$ and $\mathrm{PM}_{10}$ and are relevant to health. ${ }^{6}$

Epidemiological studies from different parts of the world have consistently identified the relation between air pollution level and health outcomes, including exacerbation of asthma, chronic bronchitis, respiratory tract infections, ischaemic heart disease and stroke. ${ }^{7}$ The automobile exhaust health effect varies in degree of severity, covering minor effects to serious illness, as well as premature death. These pollutants have a direct effect on the respiratory and cardiovascular system. $\mathrm{NO}_{2}$ and $\mathrm{SO}_{2}$ affect lung function adversely. ${ }^{8}$

Recent studies done in transport workers and other professionals exposed to ambient air pollution also suggest impairment in pulmonary function parameters. Farooque et al. (2014) compared different PFT parameters on non-smoking auto rickshaw drivers in Kozhikode city, Kerala with non-smoking males of similar socioeconomic status. Only drivers who had worked at least 5 years were included in the study. Auto rickshaw drivers were found to have deteriorated pulmonary function parameters. $\mathrm{FEV}_{1}$ in the study group was found to be $68.55 \pm 5.25$ compared to control 91.85 \pm 1.77 of percentage predicted $(\mathrm{p}<0.001)$. FVC in the auto rickshaw drivers was shown to be $61.39 \pm$
3.69 whereas that in healthy control was $83.58 \pm$ 1.92 of percentage predicted $(\mathrm{p}<0.01)$. The study group FEV1/FVC \% was $86.55 \pm 11.84$ compared to $90.63 \pm 10.81$ of percentage predicted in control $(\mathrm{p}<0.05)$ and PEFR were found to be $68.69 \pm 3.87$ and $87.83 \pm 2.60$ of percentage predicted in the study and control group respectively $(p<0.01)$. Furthermore, in the same study comparison was made among the auto rickshaw drivers on the basis of duration of work. This study showed duration has a direct effect on the pulmonary function parameters. $\mathrm{FEV}_{1}(61.05 \pm 7.24$ vs. $74.62 \pm 8.19, \mathrm{p}<$ $0.001), \operatorname{FVC}(58.92 \pm 4.26$ vs. $67.55 \pm 6.74, \mathrm{p}<0.01)$ and PEFR $(66.13 \pm 7.52$ vs. $71.07 \pm 5.6, p<0.05)$ of percentage predicted were less among the auto rickshaw drivers with more than ten years exposure than those with less than ten years exposure. ${ }^{9}$

Traffic policemen like transport workers are on the road throughout their duty hours. They share the same atmosphere as transport workers. De Toni conducted a longitudinal study in 290 traffic policemen and follow up for 5 years measuring $\mathrm{FEV}_{1}, \mathrm{FVC}$ and respiratory symptoms. There was not much drop out with $90.9 \%$ participation rate and middle-aged population with mean age $39 \pm 8.3$ years and seniority of work as $11.4 \pm 8.2$ years. Upper respiratory symptoms were significantly higher among traffic policemen (28\%) assigned to traffic control as compared to administrative workers (11\%). Interestingly, the study didn't show an accelerated decline in $\mathrm{FEV}_{1}$ and $\mathrm{FVC}$ among traffic policemen as compared to administrative police workers during 5 years follow-up. ${ }^{10}$

Respiratory impairments were seen not only on transport workers but also in all those professionals who share the same atmosphere. Rao et al. studied the pulmonary effect from oxides of nitrogen. The study showed that $\mathrm{FEV}_{1} \%$ and $\mathrm{FEF}_{25-75 \%}$ was significantly impaired in shopkeepers of highly polluted areas. ${ }^{11}$

Ambient air pollution is responsible for the death of around 3.7 million people worldwide due to various diseases as lung malignancies, Chronic Obstructive Pulmonary Disease (COPD), ischaemic heart disease, stroke and pulmonary infections which represent $6.7 \%$ of total death ${ }^{12}$ World Health Statistics on clean cities for 
2014 reveals an annual mean concentration of particulate matters $\left(\mathrm{PM}_{2.5}\right)$ in urban areas of Nepal to be $75.7 \mu \mathrm{g} / \mathrm{m}^{3}$, which is higher than the overall level in South-East Asia $\left(60.2 \mu \mathrm{g} / \mathrm{mm}^{3}\right)$, two times the level globally $\left(38.4 \mu \mathrm{g} / \mathrm{mm}^{3}\right)^{13}$ and 7.5 times the WHO ambient $\mathrm{PM}_{2.5}$ guideline $\left(10 \mu \mathrm{g} / \mathrm{mm}^{3}\right) .{ }^{14}$

According to the Environment Performance Index (EPI) 2016, air quality in Nepal remains similar ( $177^{\text {th }}$ out of 180 countries) to that of 2014 . The quality of air in Nepal is deteriorated mainly by the maximum $\mathrm{PM}_{2.5}$ concentrations in the air as shown by the rank of average exposure to $\mathrm{PM}_{2.5}$ $\left(177^{\text {th }}\right)$ and $\mathrm{PM}_{2.5}$ exceedance $\left(177^{\text {th }}\right) \cdot{ }^{15}$ This speaks of ambient air quality in Kathmandu, the largest, most populated and polluted city in the nation. In addition, the average $\mathrm{PM}_{10}$ level measured at Putalisadak was $304.94 \mu \mathrm{g} / \mathrm{mm}^{3}$ (from Kartik 2070 to Jesth 2071), significantly higher than national standard $\left(120 \mu \mathrm{g} / \mathrm{mm}^{3}\right) \cdot{ }^{16} \mathrm{As}$ a part of the profession, transport workers are exposed to pollution most of their working hours. As the burden of ambient air pollution is massive, this study will focus on the effect of occupational exposure on the pulmonary function tests in transport workers.

\section{MATERIALS AND METHODS}

This is a cross-sectional comparative study. Population was divided into two groups; transport workers (drivers and helpers) who were exposed to pollution for at least 1 year and the general public who were exposed only during their travel to work and return back home. The study was conducted at the bus stations and transport office within the Ring Road of Kathmandu valley.

Cluster random sampling method was employed. Out of total ten bus stations identified inside Ring Road of the Kathmandu, four stations (Nepal Yatayat Balkumari station, Sajha Yatayat office, Mahanagar Yatayat office, and Kantipur Yatayat Balkhu station) were randomly selected by lottery. Then, in each of the selected bus stations, all transport workers who met the inclusion criteria were selected. Controls were selected from the students studying medicine in TUTH, IOM and the administrative staffs from transportation office who met the inclusion criteria.
The sample size was determined by power calculation using software GPower (Version 3.1). According to the study by Bener et al., forced expiratory volume in one second $\left(\mathrm{FEV}_{1}\right)$ is significantly reduced among taxi drivers exposed to environmental pollution as compared to manual workers. The reduction in $\mathrm{FEV}_{1}$ was from $3.33 \pm 0.28 \mathrm{~L}$ (manual worker, control) to $3.14 \pm 0.43 \mathrm{~L}$ (taxi driver, exposed) in the study. ${ }^{17}$ Hence, with the consideration of reduction in the FEV1 from $3.33 \pm 0.28 \mathrm{~L}$ (manual worker, control) to $3.14 \pm 0.43 \mathrm{~L}$ (taxi driver, exposed), keeping level of significance $\alpha=0.05$ and with the power of $90 \%$; the sample size came out to be 78 in each group i.e. total of 156 .

\section{Inclusion criteria}

- Age 18 to 40 years.

- Working as either driver or helper for at least one year in Kathmandu Valley within the Ring Road.

- Nonsmoker.

\section{Exclusion Criteria ${ }^{18}$}

- History of myocardial infarction (within 1 month).

- Chest and abdominal pain of any cause.

- Oral or facial pain exacerbated by the mouthpiece.

- Stress incontinence.

- Dementia or confusional state.

- Obesity (BMI $\geq 30)$

- Smoker.

\section{Tools}

- Weighing machine (Krups model - Doctor Beli Ram and Sons)

- Height scale

- Spirometer (MIR Spiro III)

\section{Technique}

Following procedures was employed to carry out the PFT in both the study and control group.

- Written consent was obtained from both the case and control group after explaining the details of the study.

- A short relevant history checking exclusion criteria was taken along with the signs and symptoms of environmental pollution if present. 
- The participants performing the test were asked

- Not to wear tight clothes.

- Not to have large meals or alcohol.

- Not to do vigorous exercise within an hour before performing the procedure.

- Blood pressure, height and weight were obtained from each participant, then body mass index (BMI) was calculated by Quetelet formula.

- $\quad \mathrm{BMI}=$ Weight (in kg) $/$ Height $^{2}$ (in meter)

- Spirometry was conducted in sitting position. The procedure was explained thoroughly. After demonstrating the test to the subject, the subject was positioned correctly. Application of nose clip and proper placement of the mouthpiece in mouth and sealing the remaining space by the closed lips around the mouthpiece was taught.

- The subject was asked to inhale completely and rapidly with a pause of less than one second at total lung capacity (TLC). After a pause, the subject was asked to exhale rapidly and forcefully until no more air can be expelled out while maintaining the upright posture.

- The subject was encouraged throughout the procedure to inhale and exhale to the maximum limit.

The test was repeated at least 3 times or until reading fulfilled the American Thoracic Society (ATS) criteria for repeatability and reproducibility. Usually, no more than eight attempts were required.

\section{Statistical analysis}

The best of the reading was written in the proforma sheet along with other data. The primary raw data were entered into an Excel spreadsheet. Data were processed and analysed using Statistical Package for Social Sciences (SPSS) version 20. The results were presented as mean $\pm \mathrm{SD}$ (Standard Deviation). Independent sample t- test was used to compare the mean values of pulmonary function parameters as well as anthropometric measurements between the study group and control. P-value of $<0.05$ was considered statistically significant.
Before conducting the study, ethical clearance was taken from the institutional review board (IRB) of the Institute of Medicine (IOM)

\section{RESULTS}

Table 1: Comparison of anthropometric measurement of participants.

\begin{tabular}{|l|c|c|c|}
\hline Parameters & $\begin{array}{c}\text { Transport } \\
\text { worker(n=78) }\end{array}$ & $\begin{array}{c}\text { General } \\
\text { Public(n=78) }\end{array}$ & p value \\
\hline Age(Yrs.) & $29.68 \pm 6.74$ & $28.74 \pm 7.70$ & 0.421 \\
\hline Height $(\mathrm{m})$ & $1.66 \pm 0.0839$ & $1.66 \pm 0.0835$ & 0.939 \\
\hline Weight $(\mathrm{Kg})$ & $65 \pm 10.97$ & $66.54 \pm 9.50$ & 0.351 \\
\hline BMI $(\mathrm{Kg} / \mathrm{m} 2)$ & $23.26 \pm 3.15$ & $23.96 \pm 3.39$ & 0.186 \\
\hline
\end{tabular}

Table 1 shows the age, height, weight and BMI of both case and control groups. Transport workers were from 18 to 40 years and the general public were from 19 to 40 years. The differences in age, height, weight and BMI in these two groups were not statistically significant.

Table 2: Comparison of observed PFT parameters between transport workers and the general public.

\begin{tabular}{|l|l|l|l|}
\hline \multicolumn{1}{|c|}{ PFT parameters } & \multicolumn{1}{|c|}{$\begin{array}{c}\text { Transport } \\
\text { Workers }(\mathbf{n}=\mathbf{7 8})\end{array}$} & $\begin{array}{c}\text { General } \\
\text { Public }(\mathbf{n}=\mathbf{7 8})\end{array}$ & p value \\
\hline FVC $(\mathrm{L})$ & $3.95 \pm 0.81$ & $4.43 \pm 0.59$ & 0.000 \\
\hline FEV,$(\mathrm{L})$ & $3.10 \pm 0.61$ & $3.55 \pm 0.43$ & 0.000 \\
\hline FEV $_{1} / \mathrm{FVC} \%$ & $78.43 \pm 7.35$ & $80.26 \pm 6.48$ & 0.102 \\
\hline PEFR $(\mathrm{L} / \mathrm{Sec})$ & $6.92 \pm 1.66$ & $8.02 \pm 1.24$ & 0.000 \\
\hline FEF $25-75 \%(\mathrm{~L} / \mathrm{sec})$ & $2.88 \pm 0.83$ & $3.50 \pm 0.89$ & 0.000 \\
\hline
\end{tabular}

Table 2 shows the observed values of FVC, $\mathrm{FEV}_{1}, \mathrm{FEV}_{1} / \mathrm{FVC}, \mathrm{PEFR}$ and $\mathrm{FEF}{ }_{25-75 \%}$ of transport workers and the general public in which all the parameters in transport workers are significantly lower than in general public except $\mathrm{FEV}_{1} / \mathrm{FVC} \%$.

Table 3: Comparison of anthropometric measurement of transport workers on the basis of job duration.

\begin{tabular}{|l|c|c|c|}
\hline \multirow{2}{*}{ Parameters } & \multicolumn{2}{|c|}{$\begin{array}{r}\text { Transport workers' job } \\
\text { duration }\end{array}$} & \multirow{2}{*}{ p value } \\
\cline { 2 - 3 } & $>5$ years(n=43) & $\leq 5$ years(n=35) & \\
\hline Age (yr) & $31.65 \pm 6.06$ & $27.26 \pm 6.84$ & 0.004 \\
\hline Height (m) & $1.67 \pm 0.07$ & $1.66 \pm 0.09$ & 0.910 \\
\hline Weight $(\mathrm{kg})$ & $66.47 \pm 9.97$ & $63.20 \pm 11.98$ & 0.193 \\
\hline BMI $(\mathrm{kg} / \mathrm{m} 2)$ & $23.77 \pm 2.85$ & $22.64 \pm 3.43$ & 0.118 \\
\hline
\end{tabular}

Table 3 shows a comparison of age, height, weight and BMI of transport workers working more than 
5 years and 5 years or less. Differences in height, weight and BMI were not statistically significant. Mean age of transport workers working for more than 5 years was $31.65 \pm 6.06$ years, which is significantly higher than the mean age of those working 5 years or less (27.26 \pm 6.84 years).

Table 4: Comparison of observed PFT parameters in transport workers according to the duration of work in Kathmandu.

\begin{tabular}{|c|c|c|c|}
\hline \multirow{2}{*}{ PFT parameters } & \multicolumn{2}{|c|}{$\begin{array}{c}\text { Transport Workers' job } \\
\text { duration }\end{array}$} & \multirow{2}{*}{$\begin{array}{c}\mathrm{p} \\
\text { value }\end{array}$} \\
\hline & $\begin{array}{l}>5 \text { years } \\
(n=43)\end{array}$ & $\begin{array}{c}\leq 5 \text { years } \\
(\mathrm{n}=35)\end{array}$ & \\
\hline FVC (L) & $3.71 \pm 0.58$ & $4.25 \pm 0.95$ & 0.003 \\
\hline FEV1 (L) & $2.92 \pm 0.47$ & $3.31 \pm 0.71$ & 0.005 \\
\hline FEV1/FVC\% & $78.90 \pm 6.83$ & $77.86 \pm 8.02$ & 0.538 \\
\hline PEFR(L/Sec) & $6.98 \pm 1.43$ & $6.84 \pm 1.92$ & 0.705 \\
\hline FEF $25-75 \%(\mathrm{~L} / \mathrm{Sec})$ & $2.69 \pm 0.77$ & $3.12 \pm 0.86$ & 0.024 \\
\hline
\end{tabular}

Table 4 compares the observed PFT parameters in transport workers according to the duration of work in Kathmandu valley. FVC, FEV1 and FEF $25-75 \%$ were significantly lesser in transport worker working for more than 5 years compared to those who work 5 years or less. FEV1/FVC and PEFR are higher in workers working for more than 5 years, but the differences are not statistically significant.

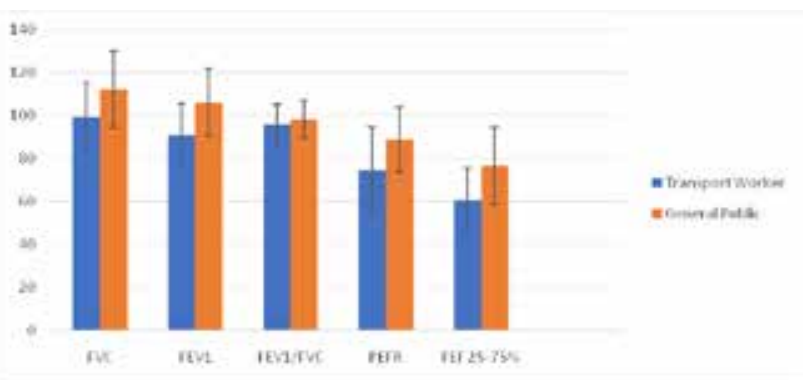

Figure I: Comparison of percent predicted of PFT parameters between transport workers and the general public

Figure Ishows percent predicted of PFT parameters in the transport workers and the general public. All the parameters in transport workers are less than their predicted values. $\mathrm{FVC}$ and $\mathrm{FEV}_{1}$ values are more than predicted in general public. FEV1/FVC, PEFR and FEF $25-75 \%$ values are less than percent predicted in general public. All the parameters in the general public are higher than transport workers.

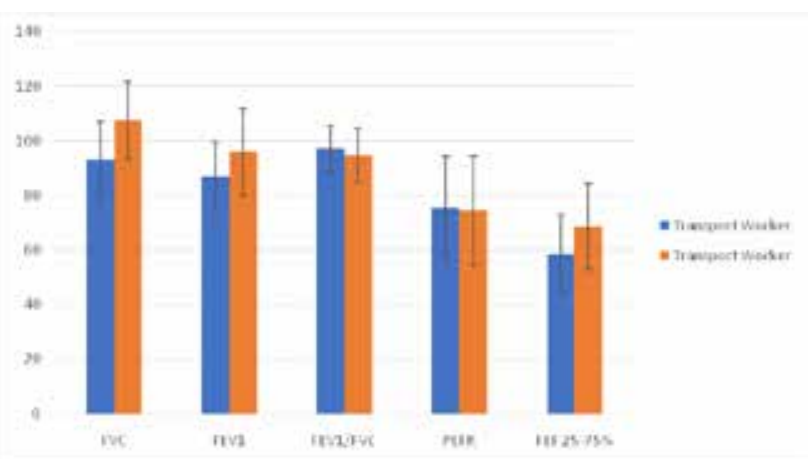

Figure II: Comparison of percent predicted of PFT parameters in transport workers according to the duration of work in Kathmandu.

Figure II compares the percent predicted of PFT parameters among transport workers according to the duration of work in Kathmandu. FVC, FEV and FEF $25-75 \%$ values are significantly reduced in transport workers who work for $>5$ years as compared to those who work for 5 years or less in similar condition. $\mathrm{FEV}_{1} / \mathrm{FVC}$ and PEFR values are slightly increased in workers working for more than 5 years.

\section{DISCUSSION}

In this study, the PFT values of transport workers are found to be deteriorated as compared to the general public. The mean values of ventilatory capacity for values measured among transport workers demonstrated significantly lower FVC, $\mathrm{FEV}_{1}, \mathrm{FEF}_{25-75 \%}$ and PEFR in transport workers as compared to the general public. Almost, all forced spirometric tests on the exposed transport workers are significantly inferior to the comparable control group $(\mathrm{p}<0.001)$ except in measured values for $\mathrm{FEV}_{1} / \mathrm{FVC}$. Also, the forced spirometric test showed statistically very highly significant differences in the percentage predicted among the transport workers and the general public concerning $\mathrm{FVC}, \mathrm{FEV}_{1}, \mathrm{FEF}_{25-}$ ${ }_{75 \%}$ and PEFR. These findings are consistent and corroborate with other reported studies by Ulfvarson et al. (1987) in Sweden, ${ }^{19}$ Zuskin et a.1 (1994) in Croatia, ${ }^{20}$ and different part of India as Jayalaxmi et al. (2015) in Chennai, ${ }^{21}$ Farooque et al (2014) in Kerala, ${ }^{9}$ Pramanik et al. (2013) in West Bengal, ${ }^{22}$ Afroz et al. (2012) in Karnataka, ${ }^{23}$ Binawara et al (2010) in Rajasthan ${ }^{24}$ and Chattopadhayay et al. (2003) in Kolkata. ${ }^{25}$ 
Pulmonary function parameters are deteriorated in transport workers engaged for a longer period as compared to those who have recently joined the profession. This finding is similar to the finding of Zuskin et a.1 (1994) in Croatia, ${ }^{20}$ and Farooque et al. (2014) in Kerala. ${ }^{9}$ Duration of exposure and deterioration of pulmonary functions as shown by this study is supported by the findings of the study done in traffic policemen from Kathmandu. ${ }^{26}$

The decrease in PFT values are because of different pollutants present in the ambient air. Deterioration of PFT values depends on the type of pollutant that is dominant. A study done by Liebrich et al. demonstrated that increase in the concentration of oxides of nitrogen and sulphur is directly related to a decrease in pulmonary function parameters, but the decrease was more pronounced with increasing $\mathrm{PM}_{10}$ concentration. With every $10 \mu \mathrm{g} / \mathrm{m}^{3}$ increase in $\mathrm{PM}_{10}$ concentration, FVC and $\mathrm{FEV}_{1}$ decreased by $3.4 \% .{ }^{27}$ Study done in two schools of Iran, one located in Teheran $\left(\mathrm{PM}_{10}=370 \mu \mathrm{g} / \mathrm{m}^{3}\right.$ in September and $65 \mu \mathrm{g} / \mathrm{m}^{3}$ in August) and other in Zanjan $\left(\mathrm{PM}_{10}<50 \mu \mathrm{g} / \mathrm{m}^{3}\right.$ annually) showed decreased pulmonary functions in students residing and studying in Teheran which is again the evidence that higher the level of particulate matter, the lower will be the values for PFT's. Teheran is one of the capital cities that is polluted by urban activites and industrial processes. ${ }^{28}$

Eight years (1987-1994) long prospective study by Sekine et al. showed that the area with the highest mean $\mathrm{NO}_{2}(0.047-0.056 \mathrm{ppm})$ and the highest mean SPM $\left(48-62 \mathrm{mg} / \mathrm{m}^{3}\right)$ had the highest annual fall in FVC (0.006 L./yr) and FEV, $(0.020 \mathrm{~L} / \mathrm{yr})$ and no fall in FVC and minimum fall in $\mathrm{FEV}_{1}(0.009 \mathrm{~L} / \mathrm{yr})$ in areas where the mean $\mathrm{NO}_{2}(0.024-0.036 \mathrm{ppm})$ and mean SPM (28-39 $\mathrm{mg} / \mathrm{m}^{3}$ ) were the lowest. ${ }^{29}$ In a cross-sectional study, Jafary et al demonstrated the inverse relation of exposure to pulmonary function parameters. People exposed to the highest level of roadside dust concentration $(4.697 \pm 0.3 \mathrm{mg} /$ $\mathrm{m}^{3}$ ) had lowest test values (FVC- $2.80 \pm 0.28 \mathrm{~L}$, $\mathrm{FEV}_{1}-2.29 \pm 0.26 \mathrm{~L}$ ) and vice versa (road side dust concentration- $1.231 \pm 0.409 \mathrm{mg} / \mathrm{m}^{3}$, FVC$\left.3.94 \pm 0.30 \mathrm{~L}_{,} \mathrm{FEV}_{1}-3.18 \pm 0.37 \mathrm{~L}\right){ }^{30}$
Qian et al. found a negative association between $\mathrm{PM}_{10}$ and $\mathrm{O}_{3}$ with FVC and $\mathrm{FEV}_{1}$ in a crosssectional study conducted on 10,240 middle-aged adults. ${ }^{31}$ Abbey et al observed that an increase in the mean $\mathrm{SO}_{4}$ concentration of $1.6 \mu \mathrm{g} / \mathrm{m}^{3}$ was associated with a $1.5 \%$ decrement in $\mathrm{FEV}_{1}$. An increase of $23 \mathrm{ppb}$ of ozone as an 8-hours average was associated with a $6.3 \%$ decrement in $\mathrm{FEV}_{1} \cdot{ }^{32}$ Forbes et al also demonstrated the negative relationship between $\mathrm{PM}_{10}$ concentration and $\mathrm{FEV}_{1} \cdot{ }^{33}$

Particulate matters, whether it be from fuel combustion in automobile engines or from any other sources are the main pollutants. These particulate matters settle along the respiratory tracts. Most of $\mathrm{PM}_{10}$ particles do not enter lungs because they are already removed by settling and impaction on nasal hairs and at bends in the flow path. Those that get entry settle in the trachea and other larger airways in small quantity, but maximum of them reach alveolar sac. Ultrafine particles $(<0.1 \mu \mathrm{m})$ have an effective deposition throughout the respiratory passage. The particles $<0.001 \mu \mathrm{m}$ have the highest deposition in the upper airways whereas $0.01 \mu \mathrm{m}$ particles deposit mostly in the alveolar region. ${ }^{34}$ Once settled many of them are removed by alveolar macrophages and some others are carried away by lymphatic drainage. Remaining particulate matters in respiratory tract start impairing mucociliary and macrophage activity along with facilitating growth of fibrous tissue in alveolar septa. It causes airway irritation, induces oxidative stress and, consequently, pulmonary inflammation. The initiation of these conditions is without symptoms but can be picked up easily by spirometer as deranged pulmonary function parameters. ${ }^{35}$

The vehicles operating inside Kathmandu valley are using mainly petroleum products as fuel. Kathmandu valley is further polluted by the stranded construction materials and roadside dust. The combination of pollutants produced by these two sources along with few industrial wastes have made the ambient air too polluted. All the professionals that are exposed to this pollution level for longer duration have detrimental health effect as decreased in pulmonary function parameters in transport workers as shown by this study. 
Being cross-sectional study, we were able to assess the pulmonary function of the subjects at that point of time only. A follow-up study would have been better at considering the rate of deterioration in pulmonary function parameters over an extended period of time.

Because of unavailability of pollutant measuring equipment, we couldn't determine the concentration of a different pollutant that transport workers are exposed to during their working hours.

Since smoking is prevalent among transport workers, the effect of passive smoking in nonsmoker group and their exposure to domestic pollution couldn't be quantified by this study.

\section{CONCLUSION}

The result of this study confirms the decreased pulmonary function parameters among the transport workers. This study also confirms deteriorated pulmonary functions in workers involved in this profession for a prolonged period in Kathmandu valley as compared to newly recruited professionals or those worked only for a few years.

Alteration in the pulmonary function parameters in the transport workers is believed to be the result of ambient air pollution, mainly contributed by stranded dust on roadsides and petroleum exhaust.

\section{REFERENCES}

1. Singh S. Environmental Geography Allahabad: Pragag pustak bhawan; 1995.

2. World Health Organisation. Public health, environmental and social determinants of health (PHE). [Online]. [cited 2016 July 18]. Available from: http://www.who.int/ phe/health_topics/outdoorair/en/.

3. Gautam DR. Air pollution: its causes and consequences with reference to Kathmandu metropolitan city. The Third Pole. 2010; 8(10): 27-33.

4. Chandrasekaran R, Samy PLP, Murthy PBK. Increased sister chromatid exchange(SCE) frequencies in lymphocytes from traffic policemen exposed to automobile exhaust pollution. Hum Exp Toxicol. 1996; 15: $301-4$
5. Gautam P, Blaha U, Erwin A, Neupane G. Environmental magnetic approach towards the quantification of pollution in Kathmandu urban area, Nepal. Phys Chem Earth. 2004; 29(13-14): 985-95.

6. World Health Organisation. Health aspects of air pollution with particulate matter, ozone and nitrogen dioxide. Copenhagen: World Health Organisation; 2003. Report No.: EUR/03/5042688.

7. Salvi S, Holgate S. Mechanisms of particulate matter toxicity. Clin Exp Allergy. 1999; 29: 1187- 94.

8. Sapkota R. vehicular pollution in kathmandu valley. J Ins Engineering. 2011; 8(1): p. 149-52.

9. Farooque I, Jayachandra S. Pulmonary function tests in nonsmoking auto rickshaw drivers. Al Ameen J Med Sci. 2014; 7(3): 240-43.

10. De Toni A, Larese Filon F, Finotto L. Respiratory diseases in group of traffic police officers: results of a 5-year followup. G Ital Med Lav Ergon. 2005; 27(3): 380-382.

11. Rao NM, Patil TS, Rajyani CV, Agrawal AL, Kulkarni PK, Chaterjee SK, Kasyap SK. Pulmonary function status of shopkeepers of Ahmedabad exposed to autoexhaust pollutants. Indian J Physiolpharmacol. 1992; 36(1): 60-64.

12. World Health Organisation. Global Health Observatory (GHO) data. [Online]. [cited 2016 july 22]. Available from: http://www. who.int/gho/phe/outdoor_air_pollution/ burden_text/en/

13. World Health Organisation. SDG Target 11.6 Clean cities. [Online]; 2014 [cited 2016 July 22]. Available from: http://apps.who. int/gho/data/node.main.SDG116?lang=en.

14. World Health Organisation. WHO Air quality guidelines for particulate matter, ozone, nitrogen dioxide and sulfur dioxide; 2005.

15. Yale university, Columbia university. Environmental Performance Index; 2016.

16. Department of Environment. Air quality data of Kathmandu valley 2013-2014. Kupandole; 2014. 
17. Bener A, Brebner J, Atta MNS, Gomes J, Ozkaragoz F, Cheema M. Respiratory symptoms and lung function in taxi drivers and manual workers. Aerobiologia. 1997; 13: 11-15.

18. Miller MR, Capro RO, Hankinson J, Brusasco V, Burgos F, Casaburi R et al. General considerations for lung function testing. Eur Respir J. 2005; 26(1): 153-61.

19. Ulfvarson U, Alexandersson R, Aringer L, Svensson E, Hedenstierna G, Hogstedt C, et al. Effects of exposure to vehicle exhaust on health. Scand J Work Environ Health. 1987; 13(6): 505-12.

20. Zuskin E, Mustajbegovic J, Schachter E. Respiratory symptoms and lung function in bus driver and mechanics. Am J Ind Med. 1994; 26: 771- 83.

21. Jayalakshmi BS, Shivkumar S. Pulmonary function tests in healthy non-smoking male transport workers - a study from Chennai, India. Natl J Res Com Med. 2015; 4(2): 192-198.

22. Pramanik P, Ganguli I, Chowdhury A, Ghosh B. A study to assess the respiratory impairments among three wheelers auto drivers. Int J Life Sci Pharma Res. 2013; 3(1): 94-99.

23. Afroz A, Veeresh S, Manjushree S, Amrutha SI. A comparative study among the three wheeler automobile drivers on pulmonary function tests in adult males of Gulbarga city. Int J Med Res Health Sci. 2013; 2(1): 35-39.

24. Binawar BJ, Gahlot S, Mathur KC, Kakwar A, Gupta R, Rajnee. Pulmonary function tests in three-wheeler diesel taxi drivers in Bikaner city. Pak J Physiol. 2010; 6(1): 2831

25. Chattopadhya BP, Alam J, Roychowdhury A. Pulmonary function abnormalities associated with exposure to automobile exhaust in a diesel bus garage and roads. Lung. 2003; 181: 291-302.

26. Shrestha HS,Nepal O, Khanal K, Kapoor BK. A cross-sectional study of lung functions.in traffic police personnel at work in kathmandu valley, Nepal. Ann Clin Chem Lab Med. 2015; 1(1):42- 48.
27. Ackermann-Liebrich U, Leuenberger $\mathrm{P}$, Schwartz J, Schindler C, Monn C, Bolognini $\mathrm{G}$, et al. Lung function and long term exposure to air pollutants in Switzerland. Am J Respir Crit Care Med. 1997; 155: 122-129.

28. Fereidoun H, Nourddin MS , Rreza NA, Mohsen A, Ahmad R, Pouria H. The effect of long-term exposure to particulate pollution on the lung function of teheranian and zanjanian students. Pak J Physiol. 2007; 3(2).

29. Sekine K, Shima M, Nitta Y, Adachi M. Long term effects of exposure to automobile exhaust on the pulmonary function of female adults in Tokyo, Japan. Occup Environ Med. 2004; 61: 350-57.

30. Jafary ZA, Faridi IA, Qureshi HJ. Effects of airborne dust on lung function of the exposed subjects. Pak J Physiol. 2007; 3(1): 30-34.

31. Qian Z, Liao D, Lin HM, Whitsel EA, Rose KM, Duan Y. Lung function and longterm exposure to air pollutants in middle-aged American adults. Arch Environ Occup Health. 2005; 60(3): 156-63.

32. Abbey DE, Burchette RJ, Knutsen SF, McDonnell WF, Lebowitz MD, Enlight PL. Long-term particulate and other air pollutants and lung function in nonsmokers. Am J Respir Crit Care Med. 1998; 158(1): 289-98.

33. Forbes LJL, Kapetanakis V, Rudnicka AR, Cook DG, Bush T, Stedman JR et al. Chronic exposure to outdoor air pollution and lung function in adults. Thorax. 2009; 64(8): 657-63.

34. Hall JE. Guyton and Hall Textbook of medical physiology. 12th Ed.: Elsevier; 2014.

35. Arbex MA, Santos UP, Martin LC, Saldiva PHN, Pereira LAA, Braga LAF. Air pollution and the respiratory system. J Bras Pneumol. 2012; 38(5): 643-55. 